\title{
Myths to Live By: Beijing Narratives
}

\section{Rosalind Eyben}

\begin{abstract}
The author draws on her own experience as a feminist bureaucrat involved in the 1995 Fourth World Conference on Women in Beijing to make the case for multiple feminist narratives of Beijing that woven together can create a myth that points to the importance of collective organising that cuts across state-civil society boundaries.
\end{abstract}

\section{Introduction}

In a recent article Cornwall and Rivas (2015) critique 'gender mainstreaming' in international development policy practice and argue that governments, UN agencies, and donor bureaucracies are limited in what they can achieve in transforming power relations. I do not dispute the authors' conclusion that the motor of change is grass roots collective organising. Nevertheless, I would not want such disenchantment with bureaucratic institutions which many others share - to lead to them ignoring the potential for political alliances with feminists working for change from inside such bureaucracies (Eyben and Turquet 2013). It matters what stories get to be told. The dominant Beijing narrative has been about the role and challenges of collective organising in seeking to shape international policy agendas. As an erstwhile feminist bureaucrat who was there, I am interested in how rarely we have been represented in Beijing narratives. Our thread is largely missing. Thus, the present article introduces a hitherto scarcely visible set of characters and an additional strand of narrative about the 1995 Beijing conference.

Emotive power converts certain historical events into myths. ${ }^{1}$ The narrative or content of such a myth shapes individual and collective identities, defines contemporary understandings, and for political activists influences future strategy. Because of their significance in the present, myths are subject to re-evaluation about what, who, why and how. Differently positioned narrators offer alternative accounts of the same event (Friedman 1992). I argue the case for multiple feminist narratives that woven together make a sturdier Beijing myth to inspire and to draw upon in present struggles.
Every now and then I find that a new acquaintance was at Beijing. She assumes that like her I was one of the 30,000 participants at the forum in Huairou and is keen to swap stories of all its excitement and diversity. She is momentarily disconcerted when I explain I was a government official on the UK delegation to the actual conference. At one such recent encounter, my acquaintance commented astutely that I probably had not had as much fun as she had had at the forum. Very true.

Gender and Development students at the Institute of Development Studies have sometimes asked me to tell them about Beijing. I feel embarrassed to tell them that the conference itself was largely a wearisome affair with little of substance discussed. There is only so much to be told about arguing over the placement of a comma. So I usually recount the few bizarre incidents I experienced outside the conference rooms. That secret meeting on a rainy afternoon with the Vatican delegate in a café at Beijing Zoo. The alleged scandalous behaviour of a certain senior Western diplomat. It has been a rather flippant performance to engage my audience's interest. Yet, I do have a Beijing narrative.

\section{A feminist bureaucrat's narrative}

Little has been published about the official delegations at Beijing nor much told about the preparations they made for the conference. ${ }^{2}$ Writing soon after the event, Ruth Dawson contrasted 'the decorous ranks of official delegates' with those at Huairou, '[the] exuberant women... myriad diverse interested parties from the national and international NGOs [non-governmental organisations] that are often the main implementers and agents of change' (1996: 7).

Dawson's account then goes on to concentrate on what happened at Huairou. Other accounts

IDS Bulletin Volume 46 Number 4 July 2015 @ 2015 The Author. IDS Bulletin (C 2015 Institute of Development Studies Published by John Wiley \& Sons Ltd, 9600 Garsington Road, Oxford OX4 2DQ, UK and 350 Main Street, Malden, MA 02148, USA 
concentrate entirely on the forum, taking care to stress the different values and expectations they encountered there but without considering to include us, the official delegates in the narrative of diversity.

Peoples' experiences were all very different and... it is impossible to give a definitive account of what took place in Beijing (Chinkin 1996: 19).

Participants went home 'with different stories' (Hershatter, Honig and Rofel 1996: 308).

Compared with the 30,000 at Huairou, there were about 10,000 people at the official conference, including 4,000 representatives of accredited NGOs who travelled back and forth between the conference and the forum. Our collective task was to finalise the Platform for Action, earlier versions of which had been discussed at global and regional preparatory sessions. The objective was to remove the square brackets from those paragraphs and sentences in the text that were still contested. I remember little of the details and therefore cannot describe except in generalities the long hours closeted in informal meeting rooms negotiating the removal of brackets from the draft text, returning back to the hotel late at night to eat a club sandwich ordered from room service and then tumble into bed. Possibly, I remember so little because by the time I arrived in Beijing on 29 August, I was already extremely tired from three years of prior negotiations.

Beijing preparations required negotiating with multiple sets of actors. For my feminist bureaucrat colleagues and me this included persuading people in our own ministry - international development ${ }^{3}$ - both in London and with the ministry's country programme heads in offices around the world; with other UK ministries in Whitehall and with the UK Mission to the United Nations; with UK NGOs and feminist academics (including a lively bunch at IDS); with the UN Division for Women in New York; at the Organisation for Economic Co-operation and Development (OECD) in Paris; within the European Commission at meetings in Brussels; and also with officials from other Commonwealth countries. And all of these people that I engaged with had their own constituencies and antagonists with whom they had to negotiate.

At the British aid ministry I was responsible for what we then called 'Women in Development' (along with other policy issues that related to discrimination and exclusion) and as such I was one of three senior officials responsible to UK government ministers for formulating the UK position on the Platform for Action. The other two were respectively the Head of the Sex Equality Branch (SEB), based in the Department of Employment but with a Whitehallwide mandate and a diplomat based at the UK Mission in New York, experts in United Nations negotiations and 'the line to take'.

SEB had to take on board the views of the different Whitehall departments while at the same time consulting with diverse civil society constituencies that came together in the Women's National Commission - Girl Scouts, the Mother's Union, the Fawcett Society and so on. We in the aid ministry had our own lobby group of development scholars and representatives of UK-based international NGOs that came together into a 'Beijing Forum'. I managed a budget within the ministry that could be used to support them in preparing their own position and thus enabling them to lobby the ministry more effectively, strengthening my hand in my internal negotiations. The lobby's voice was also important in influencing my ministry's negotiating stance within Whitehall. For example, the Lord Chancellor's Department (now the Ministry of Justice) objected to the draft paragraph in the Platform for Action relating to equal inheritance for girls and boys because at that time for the inheritance of the British crown and peerages, preference was given to male children. I was able to argue that it would be scandalous for the UK to be seen to be blocking this important paragraph and secured a compromise: while the UK would not block it, neither would we make statements in its favour.

Within the aid ministry, I negotiated with colleagues to leverage country programme budgets that financed both governmental and NGO preparations for Beijing in Africa and Asia. This was in coordination with the OECD-DAC Women in Development Experts' Group (DAC WID - now Gender Net) that together was able to finance such preparations - as well as paying transport costs to Beijing - in most aid-recipient countries. Ensuring an equitable distribution of available funds among the different recipients was a major challenge that led to the DAC WID group employing a full-time facilitator. (Our aid ministries took it in turns to pay her salary and travel costs.) The DAC WID group also had to debate its own position and on that basis I represented them at the informal drafting group the UN Division of Women organised to help produce the first version of the Platform for Action - that then got discussed and revised at a series of preparatory conferences that I attended. My diaries 
from 1992-5 reveal the increasing amount of effort and time we devoted to the Beijing preparations.

Imagine a complex network of overlapping circles of relationships. Twenty years on, is it too late for academic researchers to turn their attention to the feminist bureaucrats from all over the world involved in formulating the Platform for Action, looking at their very diverse experiences and national contexts, exploring how they negotiated support back home and navigated their way to Beijing and the hurdles they had to overcome in getting their governments to agree in principle to what is still the best global statement of a vision for women's rights? Of course there were others in the official delegations that came to block or were simply doing what they were told to do. But it was the energy of the feminists in the official delegations that I remember.

Most official delegations were a mixture of foreign ministry diplomats and staff from ministries of women's affairs or their countries' equivalent piece of national machinery. Not all of the latter were as frank about their feminism as was the Permanent Secretary from the Zimbabwean ministry who declared in one of the informal negotiating sessions that she would have betrayed women farmers back home if she failed to get equal inheritance rights into the Platform for Action. But those who reluctantly had to toe the official line, nevertheless found spaces where they could voice their true feelings. In a corridor, where none of the male leaders of her delegation were present, I overheard a young woman official from a religiously conservative state whisper to the Zimbabwean Permanent Secretary how she very much hoped that the equal inheritance paragraph would get through, despite her delegation's opposition.

In everyday life at the office back home in their own countries, feminists employed by their governments tend to be discreet about their views. In Ghana, for example, 'it would be fair to assume wariness among many bureaucrats of being labelled as activists' (Manuh, Anyidoho and Pobee-Hayford 2013: 50). I suggest that what happened in Beijing was a liberation from the normal constraints. Because everyone was talking about women's rights, closet feminists gave themselves permission to do so as well. Many of the delegates managed at least once to visit the forum. I observed the influence of its exuberance on my own minister. Towards the end of a day's outing to Huairou, while visiting the African region tent, she was asked to make an impromptu speech. I thought she would refuse. I had never seen her speak in public without reading from a draft prepared by civil servants like me. To my delighted amazement, seizing the proffered mike, she climbed up onto the small wooden platform, wiped the sweat from her brow (it was very hot and muggy in Huairou) and in a loud voice addressed her 'sisters' in a brief impassioned speech. At that moment, she was most definitely not 'decorous'.

With hindsight, I should have not been surprised. Already, the minister had decided to come to Beijing, despite the lack of interest or priority her most senior officials gave to the matter. And in the lead-up to the conference, she had introduced me to some of her fellow women politicians who out of the limelight were advocating that their political party be more proactive in securing a greater number of women representatives in parliament.

\section{Conclusion}

I wonder how many people today actually read the whole text of the Platform for Action. At 57,000 words it is the length of a short book. Some of it is almost meaningless - the consequence of bargaining and compromise. Some of the concerns emphasised in the text have become ever more important, others, over time, less so.

[It] did live on, its critics have always conceded, but only by being misunderstood and romanticised. It is the myth rather than the actual text that can be said to be the foundation of liberty...

This is Ferdinand Mount (2015: 16) writing about the eight hundredth anniversary of another great text, the Magna Carta, a copy of which translated into Spanish I most recently read hanging on the wall of a provincial lawyer's office in Chile. I hope that we can cherish and strengthen the myth of Beijing so that in 2095 our great-greatgranddaughters will see it as a significant moment in global action for greater social justice and be proud we were there. 


\section{Notes}

1 'Myths are narratives that do more than tell a good story. They are composed of a series of familiar images and devices, and work to produce an order-of-things that takes shape and has its effects through resonance with the affective dimensions of deeply held values and norms' (Cornwall 2007: 151).

\section{References}

Chinkin, C. (1996) 'Report on the Fourth United Nations Conference on Women, Beijing 1995', International Fournal of Discrimination and the Law 2.1-2: 119-27

Cornwall, A. (2007) 'Myths to Live By? Female Solidarity and Female Autonomy Reconsidered', Development and Change 38.1: 149-68

Cornwall, A. and Rivas, A-M. (2015) 'From "Gender Equality" and "Women's Empowerment" to Global Justice: Reclaiming a Transformative Agenda for Gender and Development', Third World Quarterly 36.2: 396-415

Dawson, R. (1996) 'When Women Gather: The NGO Forum of the Fourth World Conference on Women, Beijing 1995', International fournal of Politics, Culture, and Society 10.1: 7-27

Eyben, R. and Turquet, L. (eds) (2013) Feminists in Development Organizations. Change from the Margins, Rugby: Practical Action
2 Riddell-Dixon's (2002) account about the Beijing preparations in Canada is the only source I have located.

3 Then known as the Overseas Development Administration and since 1997 as the Department for International Development.

Friedman, J. (1992) 'Myth, History, and Political Identity', Cultural Anthropology 7.2: 194-210

Hershatter, G., Honig, E. and Rofel, L. (1996) 'Reflections on the Fourth World Conference on Women, Beijing and Huairou, 1995', Social fustice 23.1-2: 368-75

Manuh, T., Anyidoho, N.A. and Pobee-Hayford, F. (2013) "A Femocrat Just Doing my Job": Working within the State to Advance Women's Empowerment in Ghana', in R. Eyben and L. Turquet (eds), Feminists in Development Organizations. Change from the Margins, Rugby: Practical Action

Mount, F. (2015) 'Back to Runnymede', London Review of Books 37.8: 15-18

Riddell-Dixon, E. (2002) Canada and the Beijing Conference on Women: Governmental Politics and NGO Participation, Vancouver: UBC Press 